van Heyningen, W. E. (1959). J. gen. Microbiol. 20, 301-309.

\title{
Chemical Assay of the Tetanus Toxin Receptor in Nervous Tissue
}

\author{
BY W. E. vaN HEYNINGEN \\ Sir William Dunn School of Pathology, University of Oxford
}

\begin{abstract}
SUMMARY: The fixation of tetanus toxin by the receptor in nervous tissue is highly specific in so far as tetanus toxic protein (and toxoid to a much smaller extent), and apparently nothing else, is adsorbed from solutions of ionic strength greater than 0.15. At lower ionic strengths certain other proteins may be adsorbed by a mechanism that is probably different. The specific adsorption of toxic protein has been used as the basis of a chemical method of assay of the receptor which depends on the estimation of the amount of protein adsorbed under prescribed conditions by the unknown amount of receptor from a fixed amount of crude tetanus toxin.
\end{abstract}

In the previous paper (van Heyningen, 1959) reasons were given why it seemed unrealistic to attempt the isolation of the tetanus toxin receptor in nervous tissue unless a rapid, convenient and reasonably accurate assay for the receptor could be devised. This paper describes the development of such an assay. It is based on the premise, and subsequent demonstration, that if the receptor is specific in so far as it will adsorb only tetanus toxin and no other toxin, then it should adsorb only tetanus toxic protein, and no other protein. The adsorbed protein can be estimated chemically, and the amount adsorbed from a fixed concentration of toxin, irrespective of the purity of the toxin, is proportional to the amount of receptor added.

\section{METHODS}

The toxin and its assay, the antitoxin, the sphingolipid preparations used and the method for suspending them in water were the same as those described in the previous paper (van Heyningen, 1959). In addition a further preparation of tetanus toxin, TD 464D, kindly supplied by Dr C. G. Pope and Dr R. O. Thomson of the Wellcome Research Laboratories, was used for one experiment (see Table 1). This preparation was obtained by growing Clostridium tetani in Mueller medium for 2 days, lysing the organisms with $1.0 \mathrm{M}-\mathrm{NaCl}$ at $0^{\circ}$, filtering the extract, precipitating the toxin at $\mathrm{pH} \mathbf{7 \cdot 9}$ with $1.5 \mathrm{M}$-potassium phosphate, dissolving the precipitate in water, dialysing the solution and freeze-drying. It contained $\mathbf{4 0 . 8} \%$ protein and $360 \mathrm{~L}+$ doses $/ \mathrm{mg}$. protein, and was thus about $75 \%$ as pure as the crystalline preparation of Pillemer, Wittler, Burrell \& Grossberg (1948; see also van Heyningen, 1959). Protein was estimated with the Folin-Ciocalteau reagent by the method of Lowry, Rosebrough, Farr \& Randall (1951), with salt-free crystalline trypsin as standard. The crystalline trypsin, lysozyme and pepsin were commercial preparations (Armour Laboratories, Eastbourne); tetanus toxoid, C. welchii Types A, B, C and $\mathbf{D}$ and diphtheria crude toxin preparations were kindly supplied by Miss 
Mollie Barr and Mrs Irene Batty of the Wellcome Research Laboratories, Beckenham; the crude dysentery toxin preparation was made by extracting dysentery bacilli at $\mathrm{pH} \mathrm{11}$, and neutralizing, clarifying, dialysing and freezedrying the extract; purified serum albumin and $\alpha$ - and $\beta$-globulins were kindly supplied by Dr R. A. Kekwick of the Lister Institute, London.

All centrifuging of sphingolipid preparations was done for $1 \mathrm{hr}$. at $5600 \mathrm{~g}$ (5000 rev./min. in a $20 \mathrm{~cm}$. mean diam. angle centrifuge) in glass centrifuge tubes (cleaned with hot acid) of $6 \mathrm{~mm}$. internal and $7 \cdot 5 \mathrm{~mm}$. external diameter, $10 \mathrm{~cm}$. long. It was found to be important not to use plastic centrifuge tubes as these tended to adsorb protein.

\section{RESULTS}

The receptor adsorbs only protein from crude toxin

Figure 1, curve $a$, shows the ultraviolet absorption curve of the crude tetanus toxin preparation XW 1322 in $0.1 \mathrm{~N}-\mathrm{NaOH}$, in which $25 \%$ of the protein is toxin (van Heyningen, 1959). The curve is typical of a crude preparation of protein. Curve $b$ shows the absorption of the material obtained when a protagon suspension was added to this crude toxin, spun down, washed by resuspension in water and centrifuging and the adsorbed material dissolved in $0 \cdot 1 \mathrm{~N}-\mathrm{NaOH}$. This curve is typical of a protein (or mixture of proteins) dissolved in alkali, with the absorption maximum shifted to $290 \mathrm{~m} \mu$ and with an inflexion at about $245 \mathrm{~m} \mu$. The absorption curve, $c$, of a purified protein, crystalline trypsin, is shown for comparison. These curves show that when tetanus toxin receptor was added to crude tetanus toxin only protein, and nothing else which absorbed u.v. radiation, was adsorbed. With the amount of protagon used in this experiment it was found that all the toxin, and $22 \%$ of the protein, was adsorbed from the crude toxin preparation. Since $25 \%$ of the protein of the preparation was known to be toxin it seemed that the adsorbed protein consisted only of toxic protein. This was confirmed in the next experiment.

\section{The adsorbed protein consists only of toxic protein}

To a series of tubes containing constant amounts of toxin dissolved in constant volumes of $0 \cdot 133 \mathrm{M}$-phosphate buffer $(\mathrm{pH} 7 ; 60 \mathrm{~L}+$ doses $/ \mathrm{ml}$.) were added equal volumes of water suspensions containing increasing concentrations of receptor. After standing for $2 \mathrm{hr}$. at room temperature the tubes were centrifuged, the supernatant fluids set aside, the residues washed, and the adsorbed protein dissolved in $0 \cdot 1 \mathrm{~N}-\mathrm{NaOH}$ and estimated. The toxin contents $(\mathrm{L}+$ doses $/ \mathrm{ml}$.) of the supernatant fluids were determined by assay in mice, and the amount of adsorbed toxin calculated by difference. Figure 2 shows how closely the values for protein adsorbed as determined chemically agreed with the values for toxin adsorbed as determined by biological assay. It is clear that when the receptor was added to the crude tetanus toxin only the toxic protein was adsorbed and the irrelevant proteins unaffected, and that the more receptor was added, the more toxic protein was adsorbed. Each pair of points, 
for protein and toxin adsorbed, respectively, provides a value for the protein content of one $L_{+}+$unit of toxin; the mean for the 9 pairs of points in Fig. 2 is $1 \cdot 91 \mu \mathrm{g}$. protein $/ \mathrm{L}+$ unit. This figure compares well with the value $2 \cdot 02-2 \cdot 15 \mu \mathrm{g}$. protein $/ \mathbf{L}+$ unit which can be deduced from the data for the pure crystalline toxin of Pillemer et al. $(1948 ; 3400-3600 \mathrm{Lf} / \mathrm{mg} . \mathrm{N} ; 15 \cdot 7 \% \mathrm{~N})$, if it be assumed that since the crude and crystalline preparations have similar ratios of $\mathrm{LD} \mathrm{50/Lf}$ $(24,000$ and 18,000 , respectively) they have the same ratio of $\mathrm{Lf} / \mathrm{L}+(\mathrm{viz} .1 \cdot 146$; van Heyningen, 1959).

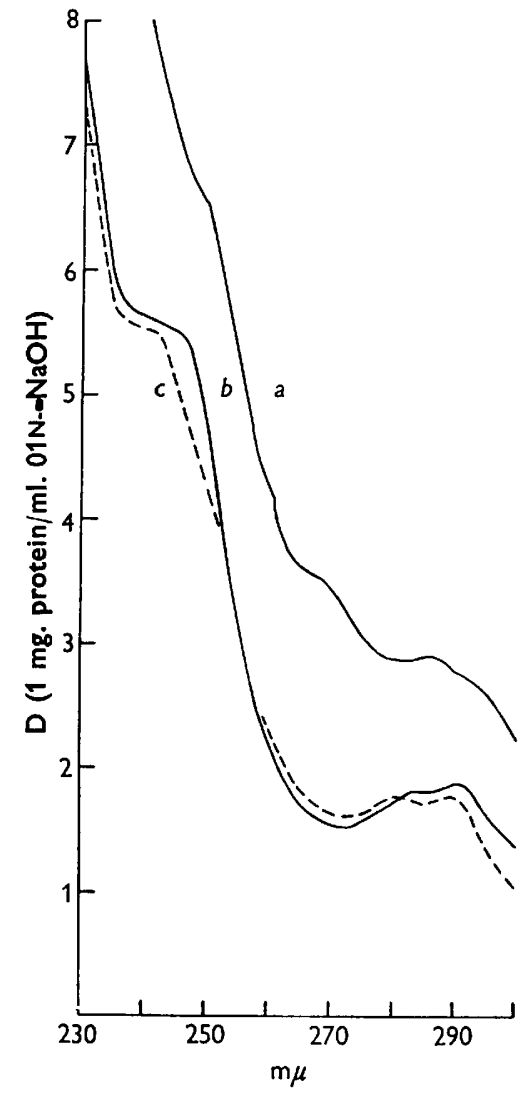

Fig. 1

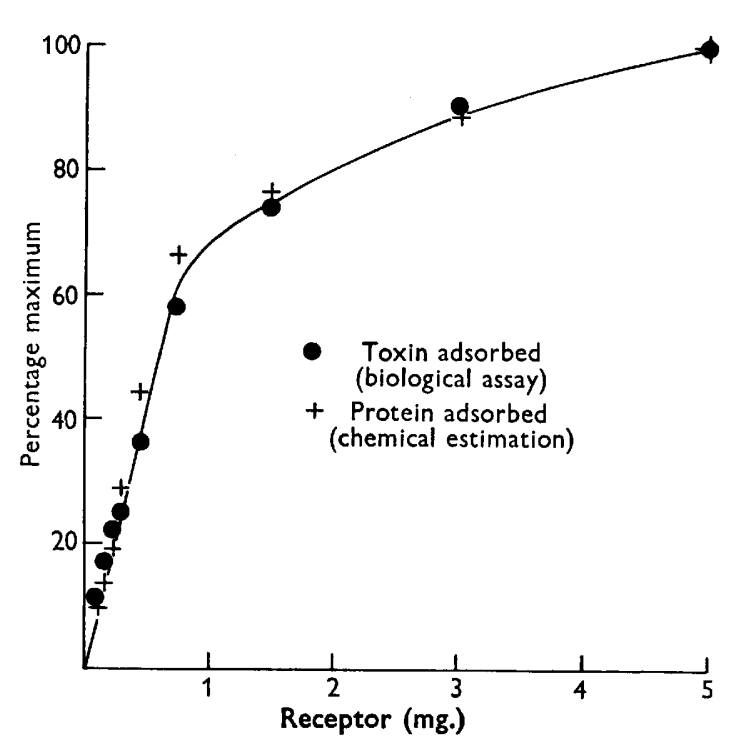

Fig. 2

Fig. 1. Ultraviolet absorption spectra of (a) crude tetanus toxin, (b) material adsorbed from crude tetanus toxin on to receptor, and (c) crystalline trypsin.

Fig. 2. Correlation between protein and toxin adsorbed from crude tetanus toxin on to receptor.

Table 1 shows that when the receptor suspension was added to solutions of a variety of preparations of toxins, enzymes and inert proteins, it adsorbed an appreciable amount of protein only from the tetanus toxin preparations, and to a lesser extent from the tetanus toxoid preparation. The preparations of tetanus toxin XW 1322 and toxoid were comparable since they were both used at a concentration of $120 \mathrm{Lf} / \mathrm{ml}$. and had the same ratio of $\mathrm{Lf} / \mathrm{mg}$. 
protein. As is known from previous work (Fulthorpe, 1956; van Heyningen, 1959), and as can be seen in Table $I$ and in Fig. 4, the amount of tetanus toxin adsorbed increased with increasing concentration of toxin. Simple extrapolation of the data for the two tetanus toxin preparations suggests that if pure toxin had been used about $150 \mu \mathrm{g}$. protein would have been adsorbed under the conditions of the experiment.

Table 1. Adsorption of protein by $250 \mu$. protagon

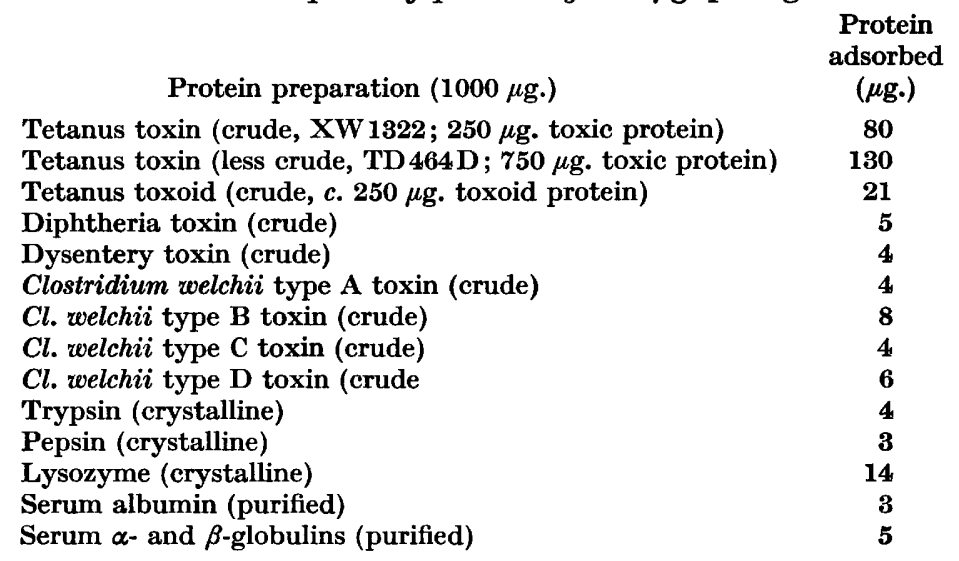

The slight adsorption of lysozyme is real, but probably unrelated to the adsorption of tetanus toxin. Figure 3 shows that adsorption of lysozyme took place at low salt concentrations, but diminished sharply as the salt concentration increased, and did not take place in solutions of ionic strength greater than 0.15 (0.067 M-phosphate buffer, pH 7). Similar results were obtained with crystalline trypsin and purified serum albumin, but not with crystalline pepsin, or with the other proteins listed in Table 1. On the other hand, the adsorption of tetanus toxin was independent of the salt content of the milieu.

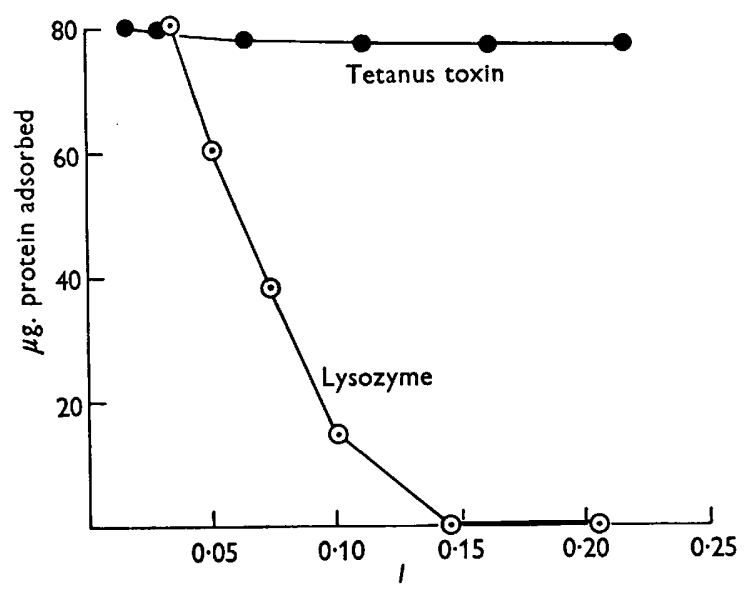

Fig. 3. Effect of ionic strength, $I$ (of phosphate buffer, pH 7 ) on adsorption of tetanus toxin $(250 \mu \mathrm{g}$.$) and lysozyme (250 \mu \mathrm{g}$.$) by receptor (250 \mu \mathrm{g}$.$) .$ 
Table 2 shows that purified cerebrosides and sphingomyelin had little capacity, as compared with crude protagon, to adsorb protein from the crude toxin preparation. Such capacity as these sphingolipids had to adsorb toxin was probably due to contamination with the receptor substance.

Table 2. Adsorption of protein from crude tetanus toxin (1 $\mathrm{mg}$. protein) by various sphingolipids (250 $\mu \mathrm{g}$.)

$\begin{array}{cc}\text { Same conditions as Table } 1 . & \begin{array}{c}\text { Protein } \\ \text { adsorbed } \\ (\mu \mathrm{g})\end{array} \\ \text { Sphingolipid } & 80 \\ \text { rude protagon } & 15 \\ \text { Prenosine } & 15 \\ \text { ixed cerebrosides } & 14\end{array}$

Optimal conditions for adsorption of toxin by receptor

Figure 4 shows the effects of various conditions on the adsorption of toxin from the crude tetanus preparation by protagon. Maximum adsorption was apparently attained within 5-10 min.; but it must be borne in mind that the protagon and the toxin preparation were in contact for a further hour during

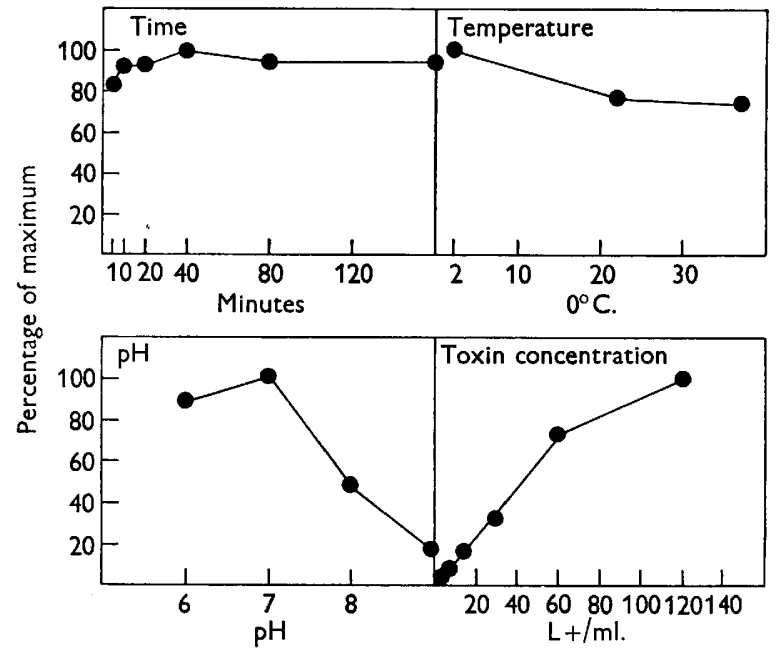

Fig. 4. Effect of various conditions on the activity of the tetanus toxin receptor.

the subsequent centrifugation. The rapid adsorption of toxin by the protagon suspension contrasts with the slower adsorption by brain (Fulthorpe, 1956; Wassermann \& Takaki, 1898). There was little difference between adsorption at $2^{\circ}$ and $37^{\circ}$. Adsorption of toxin was maximal at $\mathrm{pH}$ values around 7 , but precipitation of toxin prevented the determination of adsorption at $\mathrm{pH}$ values below 6. Adsorption of toxin increased with increasing toxin concentration, in confirmation of Fulthorpe's (1956) observations with dried brain. The 
fact that the adsorption of tetanus toxin was independent of salt concentration has already been noted in Fig. 3, and the effect of concentration of receptor has been seen in Fig. 2.

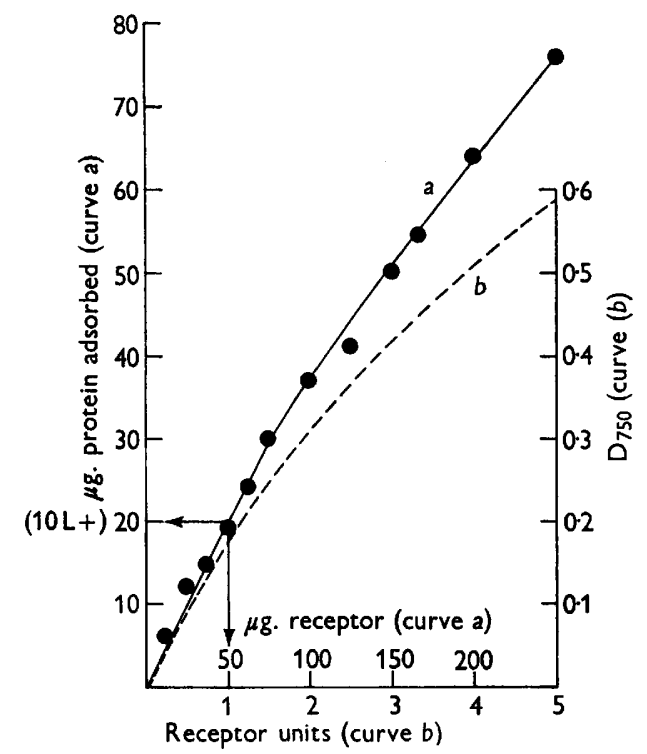

Fig. 5. Activity curve (a) and standard curve (b) derived from it for assay of tetanus toxin receptor.

The activity curve and the standard curve

On the basis of the information conveyed in Figs. 3 and 4 the data for the steep part of the curve in Fig. 2 were redetermined under optimal conditions, and plotted in Fig. 5, curve $a$. It was decided to work at a final toxin concentration of $60 \mathrm{~L}+/ \mathrm{ml}$., the best compromise between high adsorption and high consumption of toxin. The data were determined as follows. To a series of $1 \mathrm{ml}$. volumes containing $120 \mathrm{~L}+$ units of toxin $(7.68 \mathrm{mg}$. toxin preparation $\mathrm{XW} 1322$, 1.04 mg. protein)/ml. 0.133 M-phosphate buffer ( $\mathrm{pH} 7$ ) were added equal volumes of aqueous suspensions containing increasing amounts (12.5-250 $\mu \mathrm{g}$.) of protagon. After standing for $10 \mathrm{~min}$. at room temperature the mixtures were centrifuged, the supernatant fluids gently sucked off, and the gelatinous pellets of residue gently rinsed several times with water. The residues were then suspended in $3 \mathrm{ml}$. of Reagent $\mathrm{C}$ of Lowry et al. $(1951 ; 50 \mathrm{ml} .2 \%(\mathrm{w} / \mathrm{v})$ $\mathrm{Na}_{2} \mathrm{CO}_{3}$ in $0.1 \mathrm{~N}-\mathrm{NaOH}+1 \mathrm{ml} .0 \cdot 5 \%(\mathrm{w} / \mathrm{v}) \mathrm{Cu}_{2} \mathrm{SO}_{4} .5 \mathrm{H}_{2} \mathrm{O}$ in $1 \%(\mathrm{w} / \mathrm{v})$ sodium tartrate). After $10 \mathrm{~min} .0 .25 \mathrm{ml}$. Folin-Ciocalteau reagent (N-acid) was added, and after a further $30 \mathrm{~min}$. the solutions were clarified by centrifugation and the light absorption at $750 \mathrm{~m} \mu$ determined. From a standard curve obtained with crystalline trypsin treated with the same reagents the amounts of protein adsorbed on the different amounts of protagon, and dissolved by Reagent $\mathrm{C}$, were determined, and a smooth activity curve (Fig. 5a) drawn through the points thus obtained. A Receptor Unit (RU) was arbitrarily defined as the amount of receptor that would fix $10 \mathrm{~L}+$ units (i.e. $20 \mu \mathrm{g}$. at $2 \mu \mathrm{g} . / \mathrm{L}+$ ) of 
toxin (see Discussion, van Heyningen, 1959) and the weight of receptor corresponding to this unit was read off from the activity curve. In the case of the particular preparation of protagon used for this work the Receptor Unit happened to be exactly $50 \mu \mathrm{g}$. The smooth curve in Fig. $5 a$ was then replotted to give the standard curve in Fig. $5 b$ with Receptor Units on the abscissa and colour developed $\left(D_{750}\right)$ by the adsorbed protein on the ordinate. The RU by the chemical assay should be smaller than the RU-20 L + by the biological assay (van Heyningen, 1959) since the chemical assay is determined not only against a smaller amount of toxin, but also in a greater concentration of toxin, in which a greater amount is adsorbed/unit weight receptor.

Table 3. Reproducibility of chemical assays of receptor activity of a particular preparation of protagon as determined on a number of occasions

$\begin{array}{cc}\begin{array}{c}\text { Time after } \\ \text { first assay } \\ \text { (days) }\end{array} & \begin{array}{c}\text { RU/mg. } \\ \text { protagon }\end{array} \\ 0 & 20 \\ 0 & 20 \\ 0 & 19 \\ 3 & 21 \\ 7 & 20 \\ 15 & 17\end{array}$

$\begin{array}{cc}\begin{array}{c}\text { Time after } \\ \text { first assay } \\ \text { (days) }\end{array} & \begin{array}{c}\text { RU/mg. } \\ \text { protagon }\end{array} \\ \mathbf{3 0} & \mathbf{2 0} \\ 43 & 21 \\ 60 & 19 \\ 61 & 18 \\ 71 & 18 \\ 90 & 19\end{array}$

The procedure for determining the receptor activity $(\mathrm{RU} / \mathrm{ml}$.) of an unknown preparation is simple. The weighed sample is suspended in a suitable volume of water in the usual way and a $1 \mathrm{ml}$. sample of the suspension added to $1 \mathrm{ml}$. of toxin solution containing $120 \mathrm{~L}+/ \mathrm{ml}$. 0-133 M-phosphate buffer $(\mathrm{pH} 7)$. The procedure described in the previous paragraph is then carried out, except that the value for $D_{750}$ is translated directly into $R U$ by means of the standard curve. A capable technician can easily carry out 20 to 50 assays in $2 \frac{1}{2}-3 \mathrm{hr}$. Table 3 shows that the assays are reasonably reproducible.

\section{DISCUSSION}

The main object of the work reported in this paper was to develop a convenient, quick and reliable method for assaying the receptor; this appears to have been achieved. This work also demonstrates the highly specific affinity of the receptor substance in the grey matter of nervous tissue for tetanus toxin, and thus enhances the significance of the Wassermann-Takaki phenomenon. It increases confidence in the possibility that the receptor might play a part in the action of the toxin, and that combination between these might be the first step leading to the biochemical lesion underlying the pharmacological action of the toxin. The fixation of other proteins, such as lysozyme and trypsin, is probably fortuitous, and irrelevant under physiological conditions of salt concentration. Figure 3 shows that it is abolished in the presence of quite low concentrations of salt, and is therefore likely to be due to electrostatic forces. These forces are unlikely to be responsible for the specific fixation of tetanus toxin, which is unaffected by salt. 
The specificity of the receptor for the toxin suggests a number of possibilities which have not yet been explored. Thus it might prove possible to develop a simple means of obtaining highly purified toxin from crude preparations by adsorbing the toxin on protagon, centrifuging and washing the protagon toxin complex, and recovering the toxin from it by dissociation. It should also be possible to assay the toxin, to determine the purity of crude preparations, and to establish whether or not the toxin is identical with a given component of a crude preparation.

The fact that tetanus toxoid retains, although to a much smaller extent, its capacity to be adsorbed by protagon does not necessarily contradict the observations of Pons (1938) and Fulthorpe (1956) that toxoid was not adsorbed by fresh or dried brain, since the receptor activity of protagon is about 40 times as great as that of dried brain. Competitive adsorption of tetanus toxoid is probably responsible for the protective effect of toxoid observed by Lemétayer et $a l .(1950,1954)$ and by Raynaud et al. (1951) in circumstances where a high concentration of toxoid might compensate for its relatively low affinity for the receptor. They showed that previous injection of massive doses of tetanus toxoid into mice or guinea-pigs delayed or prevented death from the injection $24 \mathrm{hr}$. later of an otherwise lethal dose of toxin. Raynaud \& Wright (1953) reported that the protective effect was shown only by tetanus toxoid and not by diphtheria toxoid. This phenomenon is also no doubt related to Wolters \& Fischoeder's (1954) and Fulthorpe's (1956) findings that when brain tissue was first exposed to tetanus toxoid its capacity to absorb tetanus toxin was diminished. However, Fulthorpe showed that diphtheria toxoid also inhibited the capacity of brain to adsorb tetanus toxin.

It was shown in the previous paper (van Heyningen, 1959) that the brain of the highly resistant chicken has the same capacity to fix toxin as the brain of susceptible animals. Evidently the insusceptibility of the chicken is not due to a lack of the receptor in its nervous tissue, but to other causes, which may be connected with the fact that injected toxin disappears rapidly from the circulation of mammals, but not of chickens (see Fildes, 1929). In the present and previous papers it has been shown that the fixation of toxin is unaffected by temperature, which suggests that the fixation of toxin on the receptor is not directly connected with the fact that the toxin is ineffective at lower temperatures, but effective at higher temperatures, in poikilothermic animals, such as the frog (see Fildes, 1929; Wright, 1955).

\section{REFERENCES}

Findes, P. (1929). Medical Research Council: A System of Bacteriology in Relation to Medicine, 3, 298. London: H.M. Stationery Office.

Fulthorpe, A. J. (1956). Adsorption of tetanus toxin by brain tissue. J. Hyg., Camb. 54, 315.

Lemétayer, E., Nicol, L., Girard, D., Corvazier, R. \& Cheyroux, M. (1950). Recherches expérimentales sur les interactions du serum, l'anatoxine, de la toxine spécifique et des tissus dans le traitement prevéntif et curatif de l'intoxication tétanique. Ann. Inst. Pasteur, 79, 672. 
Lemétayer, E., Raynaud, M., Nicol, L. \& Turpin, A. (1954). Action préventive spécifique précoce de l'anatoxine tétanique employée à doses massives. Ann. Inst. Pasteur, 87, 1.

Lowry, O. H., Rosebrough, N. J., Farr, A. L. \& Randall, R. J. (1951). Protein measurement with the Folin phenol reagent. J. biol. Chem. 193, 265.

Pillemer, L., Wittler, R. G., Burreli, J. I. \& Grossberg, D. B. (1948). The immunochemistry of toxins and toxoids. VI. Crystallization and characterization of tetanal toxin. J. exp. Med. 88, 205.

Pons, L. (1938). L'anatoxine tétanique est-elle une toxine ayant perdu son pouvoir de fixation sur le système nerveux? C.R. Soc. Biol., Paris, 129, 209.

Raynaud, M., Lemétayer, E., Turpin, A., Nicol, L. \& Rouyer, M. (1951). Installation rapide d'un état de resistance a l'intoxication tétanique expérimentale par l'influence de doses massives d'anatoxine tétanique. C.R. Acad.Sci., Paris, 233, 586.

Raynaud, M. \& Wright, E. A. (1953). Rapid specific preventive action of tetanus toxoid. Nature, Lond. 171, 797.

van Heyningen, W. E. (1959). The fixation of tetanus toxin by nervous tissue. J. gen. Microbiol. 20, 291.

WassermanN, A. \& TAKAKI, T. (1898). Über tetanusantitoxische Eigenschaften des normalen Centralnervensystems. Berl. klin. Wschr. 35, 5.

Wolters, K. L. \& Fischoeder, E. (1954). Uther die Bindung von Tetanustoxin an Hirnsubstanz ohne und nach Vorbehandlung mit Tetanustoxoid. Z. Hyg. InfektKr. 139, $\mathbf{5 4 1}$.

Wright, G. P. (1955). The neurotoxins of Clostridium botulinum and Clostridium tetani. Pharmacol. Rev. 7. 413.

(Received 17 October 1958) 